\title{
CHANGES IN SERUM AND URINARY URIC ACID WITH THE DEVELOPMENT OF SYMPTOMATIC GOUT *
}

\author{
By JOHN H. AYVAZIAN $\Lambda$ ND L. FRED AYVAZIAN \\ (Lrom the Medical Scrvice, Vetcrans Administration Hospital, Nczu York, N. Y.)
}

(Submitted for publication May 7, 1963; accepted August 1, 1963)

In a recent study of gouty subjects, urinary excretion of uric acid was noted to be greater in the symptomatic than in the asymptomatic subjects (1). Since, however, the groups of patients were small and the data unpaired, these observations were not analyzed further. A review of published reports revealed lack of agreement about changes in serum and urinary uric acid during clinically active gout. Brøchner-Mortensen (2), summarizing publications to 1939 , called attention to German reports that uric acid excretion increased greatly during acute attacks of gout and subsided thereafter. Brøchner-Mortensen considered, however, that the reported fluctuations in uric acid excretion were inconstant when set against variations in medication and diet. Despite individual case reports indicating increased uricosuria during gouty attacks $(3,4)$, Stetten's view that "when an acute attack does occur no consistent changes in the quantity of uric acid in blood or urine are observed" (5), represents the consensus of current opinion.

The present study was designed to extend our previous findings by obtaining paired data from gouty men during symptomatic and asymptomatic phases of their disease, simultaneously eliminating, whenever possible, other factors that might influence uric acid metabolism and turnover.

\section{METHODS}

Over a 2-year span, data were collected from eleven subjects judged suitable for this study. All were men with previously established diagnoses of primary gout, with no detectable nephropathy, and with totally asymptomatic intercritical intervals. Pertinent data for all subjects are listed in Table I. Only three were later eliminated, two for failure to collect total urine output, and one because of the inadvertent medication with a uricosuric drug during a symptomatic episode. Ten of the subjects were followed over a single hospital ad-

* Work supported by U. S. Public Health Service research grant AI 02757-05 from the National Institute of Allergy and Infectious Diseases, Bethesda, Md. mission; eight were admitted with acute arthritis and were studied before and after therapy with colchicine and relief of symptoms. The remaining two, RC and FC, were admitted for unrelated reasons and developed acute arthritis during the study. The eleventh subject, LM, was seen over two separate admissions, once for acute arthritis, when only acute-phase data were studied, and again, 2 years later, during ambulatory convalescence from myocardial infarction.

None of the subjects were on uricosuric drugs before the study. They were all fed a standard low-purine diet from at least 2 days before the start of the study. The daily diet contained $96 \mathrm{~g}$ protein, $85 \mathrm{~g}$ fat, and $257 \mathrm{~g}$ carbohydrate; the purine content was limited to $60 \mathrm{mg}$ contained in one meat course given each day. Dietary intake was supervised daily. Three normal persons fed this diet for 7 to 11 days each stabilized their urinary excretion of uric acid within 24 to 48 hours, and thereafter their daily uric acid excretion did not vary by more than $68 \mathrm{mg}$ from their individual mean 24-hour uric acid excretion. The subjects' total urine output was collected in 24-hour samples starting and ending at 8:30 a.m. Blood was drawn each day at the same hour. Collection and preservation of urine has been described (6). Uric acid was measured by the spectrophotometric method of Praetorius and Poulsen (7) with uricase, and creatinines were determined by Phillips' modification of the alkaline picrate method (8). Urinary 17-hydroxycorticosteroids were analyzed by the method of Silber and Porter (9).

Therapy during the acute phase of the study was limited to nonuricosuric analgesics. The acute phase of the study was terminated by iv colchicine therapy in order to avoid any possible gastroenteritis that might interfere with urine collection. The usual regimen was 3 mg intravenously, followed in 12 hours by maintenance oral medication. Six of the eight subjects admitted with acute arthritis responded within 24 to 48 hours. The remaining two required a second iv dose and were free of symptoms within 72 hours. Data obtained during this transitional phase are not included in this study, and showed only decreases in uric acid excretion to levels observed in the asymptomatic period. The asymptomatic phase of the study was marked from the time at which the patient became afebrile, ambulatory, and free of objective signs of arthritis or inflammation.

\section{RESULTS}

Clinical laboratory data from the eleven gouty subjects are listed in Table I. All had absolute 
TABLE I

Summary of clinical data for gouty subjects

\begin{tabular}{|c|c|c|c|c|c|c|c|c|}
\hline \multirow[b]{2}{*}{ Subject } & \multirow[b]{2}{*}{ Age } & \multirow[b]{2}{*}{$\begin{array}{l}\text { Duration } \\
\text { of gout }\end{array}$} & \multirow[b]{2}{*}{$\begin{array}{l}\text { Blood urea } \\
\text { nitrogen }\end{array}$} & \multirow{2}{*}{$\begin{array}{c}\text { Clearance } \\
\text { endogenous } \\
\text { creatinine }\end{array}$} & \multicolumn{2}{|c|}{ Leukocytes } & \multicolumn{2}{|c|}{$\begin{array}{l}\text { Excretion of } \\
\text { 17-hydroxycorticosteroid* }\end{array}$} \\
\hline & & & & & $\begin{array}{l}\text { Asympto- } \\
\text { matic }\end{array}$ & $\begin{array}{l}\text { Sympto- } \\
\text { matic }\end{array}$ & $\begin{array}{l}\text { Asympto- } \\
\text { matic }\end{array}$ & $\begin{array}{l}\text { Sympto- } \\
\text { matic }\end{array}$ \\
\hline & years & years & $m g / 100 m l$ & $m l / m i n$ & \multicolumn{2}{|c|}{ cells $/ \mathrm{mm}^{3}$} & \multicolumn{2}{|c|}{$m g / 24$ hours } \\
\hline I.S. & 41 & 8 & 20 & 131 & 9,380 & 10,100 & 9.4 & 11.8 \\
\hline M.V. & 61 & 11 & 20 & 90 & 8,460 & 14,600 & & \\
\hline D.F. & 50 & 4 & 11 & 99 & 8,100 & 12,600 & & \\
\hline P.G. & 41 & 5 & 16 & 128 & 5,600 & 9,780 & & \\
\hline R.C. & 59 & 3 & 18 & 102 & 5,240 & 11,700 & 10.8 & 17.2 \\
\hline J.C. & 58 & 3 & 17 & 98 & 7,770 & 19,000 & & \\
\hline O.H. & 44 & 7 & 17 & 105 & 7,800 & 19,500 & & \\
\hline L.M. & 40 & 6 & 16 & 124 & 7,200 & 13,400 & & \\
\hline E.D. & 53 & 4 & 13 & 97 & 7,160 & 18,800 & 9.3 & 12.6 \\
\hline A. R. & 48 & 8 & 17 & 143 & 7,480 & 15,600 & 9.1 & 11.9 \\
\hline F.C. & 44 & 2 & 14 & 110 & 9,420 & 15,800 & 16.2 & 31.3 \\
\hline
\end{tabular}

* Normal range: 3.0 to $10.3 \mathrm{mg}$ per 24 hours.

or relative leukocytosis during the symptomatic period. Also, all five subjects so studied had increased 24-hour urinary 17 -hydroxycorticosteroid excretion during the arthritic state.

Eight of the eleven subjects were observed for 3 days before treatment with colchicine while they were symptomatic and for 3 more days while asymptomatic. For the remaining three subjects (DF, PG, and JC), data were collected for only 2 days for each period, since they received colchicine after the second day of the acute-phase study. The data are summarized in Table II, in terms of the mean values of serum and urinary uric acid and the renal clearance of uric acid for

TABLE II

Summary of data on uric acid in symptomatic and asymptomatic periods of gout*

\begin{tabular}{|c|c|c|c|c|c|c|c|c|c|}
\hline \multirow[b]{2}{*}{ Subject } & \multicolumn{3}{|c|}{ Asymptomatic period } & \multicolumn{3}{|c|}{ Symptomatic period } & \multicolumn{3}{|c|}{ Difference between periods } \\
\hline & Serum & Urine & $\mathrm{Cua}_{\mathrm{ua}}$ & Serum & Urine & $\mathrm{C}_{\mathrm{ua}}$ & Serum & Urine & $\mathrm{Cua}_{\mathrm{ua}}$ \\
\hline I.S. & $\begin{array}{c}m g / 100 m l \\
8.5 \\
8.0-8.8\end{array}$ & $\begin{array}{c}\begin{array}{c}m g / 24 \\
\text { hours } \\
568 \\
529-600\end{array}\end{array}$ & $\begin{array}{c}m l / \min \\
4.6 \\
4.5-4.7\end{array}$ & $\begin{array}{c}m g / 100 m l \\
9.5 \\
8.9-10.0\end{array}$ & $\begin{array}{c}m g / 24 \text { hours } \\
674 \\
627-723\end{array}$ & $\begin{array}{c}m l / m i n \\
4.9 \\
4.9-5.0\end{array}$ & $\begin{array}{l}\mathrm{mg} / \\
100 \mathrm{ml} \\
+1.0\end{array}$ & $\begin{array}{c}m g / 24 \\
\text { hours } \\
+106\end{array}$ & $\begin{array}{c}m l / \\
m i n \\
+0.3\end{array}$ \\
\hline M.V. & $\begin{array}{c}10.5 \\
10.1-10.8\end{array}$ & $\begin{array}{c}407 \\
376-446\end{array}$ & $\begin{array}{c}2.7 \\
2.6-3.1\end{array}$ & $\begin{array}{c}11.8 \\
11.4-12.2\end{array}$ & $\begin{array}{c}574 \\
536-630\end{array}$ & $\begin{array}{c}3.4 \\
3.3-3.6\end{array}$ & +1.3 & +167 & +0.7 \\
\hline D.F. & $\begin{array}{c}7.7 \\
7.5-7.8\end{array}$ & $\begin{array}{c}378 \\
367-388\end{array}$ & $\begin{array}{c}3.5 \\
3.3-3.6\end{array}$ & $\begin{array}{c}7.9 \\
7.6-8.1\end{array}$ & $\begin{array}{c}592 \\
479-704\end{array}$ & $\begin{array}{c}5.2 \\
4.4-6.0\end{array}$ & +0.2 & +214 & +1.7 \\
\hline P.G. & $\begin{array}{c}8.1 \\
7.9-8.3\end{array}$ & $\begin{array}{c}566 \\
544-588\end{array}$ & $\begin{array}{c}4.9 \\
4.6-5.2\end{array}$ & $\begin{array}{c}8.4 \\
7.6-8.9\end{array}$ & $\begin{array}{c}793 \\
722-863\end{array}$ & $\begin{array}{c}6.7 \\
6.6-6.7\end{array}$ & +0.3 & +227 & +1.8 \\
\hline R.C. & $\begin{array}{c}6.1 \\
5.9-6.2\end{array}$ & $\begin{array}{c}556 \\
509-595\end{array}$ & $\begin{array}{c}6.4 \\
5.8-6.7\end{array}$ & $\begin{array}{c}6.1 \\
6.0-6.2\end{array}$ & $\begin{array}{c}797 \\
713-872\end{array}$ & $\begin{array}{c}9.0 \\
8.0-9.8\end{array}$ & 0 & +241 & +2.6 \\
\hline J.C. & $\begin{array}{c}6.6 \\
6.4-6.8\end{array}$ & $\begin{array}{c}350 \\
325-374\end{array}$ & $\begin{array}{l}3.7 \\
3.5-3.8\end{array}$ & $\begin{array}{c}7.0 \\
6.9-7.1\end{array}$ & $\begin{array}{c}606 \\
597-615\end{array}$ & $\begin{array}{l}6.0 \\
6.0\end{array}$ & +0.4 & +256 & +2.3 \\
\hline O.H. & $\begin{array}{c}6.6 \\
6.5-6.8\end{array}$ & $\begin{array}{c}421 \\
377-495\end{array}$ & $\begin{array}{c}4.4 \\
3.9-5.2\end{array}$ & $\begin{array}{c}6.8 \\
6.0-7.4\end{array}$ & $\begin{array}{c}706 \\
701-717\end{array}$ & $\begin{array}{c}7.2 \\
6.7-8.1\end{array}$ & +0.2 & +285 & +2.8 \\
\hline L.M. & $\begin{array}{c}10.5 \\
10.3-10.6\end{array}$ & $\begin{array}{c}784 \\
770-802\end{array}$ & $\begin{array}{c}5.2 \\
5.0-5.4\end{array}$ & $\begin{array}{c}9.7 \\
9.1-10.1\end{array}$ & $\begin{array}{c}968 \\
934-1,025\end{array}$ & $\begin{array}{c}6.9 \\
6.4-7.2\end{array}$ & -0.8 & +184 & +1.7 \\
\hline E.D. & $\begin{array}{c}8.2 \\
7.7-8.6\end{array}$ & $\begin{array}{c}451 \\
432-475\end{array}$ & $\begin{array}{c}3.8 \\
3.8-3.9\end{array}$ & $\begin{array}{c}8.9 \\
7.8-9.9\end{array}$ & $\begin{array}{c}792 \\
689-918\end{array}$ & $\begin{array}{c}6.3 \\
4.8-8.2\end{array}$ & +0.7 & +341 & +2.5 \\
\hline A.R. & $\begin{array}{c}6.8 \\
6.6-7.0\end{array}$ & $\begin{array}{c}602 \\
562-626\end{array}$ & $\begin{array}{c}6.2 \\
5.6-6.6\end{array}$ & $\begin{array}{c}7.1 \\
6.8-7.3\end{array}$ & $\begin{array}{c}927 \\
837-1,091\end{array}$ & $\begin{array}{l}9.1 \\
8.2-10.4\end{array}$ & +0.3 & +325 & +2.9 \\
\hline F.C. & $\begin{array}{c}11.3 \\
10.9-11.5\end{array}$ & $\begin{array}{c}522 \\
505-533\end{array}$ & $\begin{array}{c}3.2 \\
3.1-3.4\end{array}$ & $\begin{array}{c}7.9 \\
7.6-8.2\end{array}$ & $\begin{array}{c}1,060 \\
900-1,142\end{array}$ & $\begin{array}{c}9.4 \\
8.0-10.4\end{array}$ & -3.4 & +538 & +6.2 \\
\hline
\end{tabular}

* Mean values and ranges are given. $\mathrm{C}_{\mathrm{ua}}=$ renal clearance of uric acid. 
TABLE III

Uric acid data in two subjects developing arthritis

\begin{tabular}{|c|c|c|c|c|c|c|}
\hline \multirow[b]{2}{*}{ Day } & \multicolumn{3}{|c|}{ Subject RC } & \multicolumn{3}{|c|}{ Subject FC } \\
\hline & Serum & Urine & Clinical state & Serum & Urine & Clinical state \\
\hline & $\mathrm{mg} / 100 \mathrm{ml}$ & $\mathrm{mg} / 24$ hours & & $\mathrm{mg} / 100 \mathrm{ml}$ & $\mathrm{mg} / 24$ hours & \\
\hline 1 & 6.1 & 509 & Asymptomatic & 10.9 & 527 & Asymptomatic \\
\hline 2 & 6.2 & 595 & Asymptomatic & 11.4 & 505 & Asymptomatic \\
\hline 3 & 5.9 & 566 & Asymptomatic & 11.5 & 533 & Asymptomatic \\
\hline 4 & 6.3 & 590 & Asymptomatic & 11.7 & 495 & Asymptomatic \\
\hline 5 & 6.3 & 603 & Asymptomatic & 12.0 & 603 & Rhinitis and pharyngitis \\
\hline 6 & 6.2 & 715 & Asymptomatic & 11.3 & 571 & Rhinitis and pharyngitis \\
\hline 7 & 6.0 & 806 & Arthritis & 12.1 & 671 & Sinusitis \\
\hline 8 & 6.2 & 872 & Arthritis & 10.7 & 779 & Sinusitis \\
\hline 9 & 6.2 & 713 & Arthritis & 8.2 & 1,142 & Arthritis \\
\hline 10 & & & & 7.6 & 1,137 & Arthritis \\
\hline 11 & & & & 7.8 & 900 & Arthritis \\
\hline
\end{tabular}

each period and their ranges. Greater excretions and renal clearances of uric acid were found in all eleven subjects while their disease was symptomatic; excretion increased from 106 to $538 \mathrm{mg}$ of uric acid per 24 hours, and the calculated renal clearance rose by 0.3 to $6.2 \mathrm{ml}$ per minute. Serum levels of uric acid changed variably, rising in eight subjects, falling in two, and remaining virtually unchanged in one. Statistical analysis by means of the Wilcoxan's signed-ranks test for matched pairs (10) shows the increased urinary excretion and renal clearance of uric acid to be significant with a $\mathrm{p}$ of less than 0.01 , whereas the changes in the serum values are not statistically significant.

Data from the two subjects who developed acute arthritis during the study are listed in detail in Table III. Both subjects increased their excretion of uric acid before developing clinical arthritis. FC developed a viral infection of the upper respiratory tract 4 days before and an acute, purulent sinusitis 2 days before his arthritis became symptomatic. No obvious precipitating cause was detected for $\mathrm{RC}$, but his uric acid excretion increased at least 24 hours before the development of an acute monoarthritis, which was noted at the completion of the seventh day of urine collection.

The failure to observe any significant changes in the serum uric acid of the gouty subjects during the two clinical phases prompted an additional study. Similar studies were conducted on a group of nongouty persons with inflammation and obviously increased nucleic acid production. Table IV lists the data obtained from seven subjects with acute nongouty arthritis or suppurative lung dis- ease. In all seven, uric acid excretion and clearance were considerably elevated, despite the absence of hyperuricemia. Serum uric acid levels ranged from 2.2 to $4.7 \mathrm{mg}$ per $100 \mathrm{ml}$, well within the normal range, whereas urinary excretion and clearance ranged from 733 to $1,330 \mathrm{mg}$ per 24 hours and 15.6 to $29.0 \mathrm{ml}$ per minute, values two to three times the normal.

\section{DISCUSSION}

Our observations raise two questions. First, what is the source or mechanism of the increased uric acid excretion and clearance in symptomatic gout? Second, are these changes the cause or the result of the arthritis? If a significant change in serum uric acid had accompanied the increased uric acid excretion, then these changes could have been attributed to either increased production of uric acid, or increased renal tubular clearance, depending on the direction of change in serum levels.

TABLE IV

Uric actd data in seven nongouty subjects with active inflammation, or suppuration, or both

\begin{tabular}{llcrr}
\hline Subject & \multicolumn{1}{c}{ Diagnosis } & Serum & Urine & $\mathrm{C}_{\text {ua }}$ * \\
& & $\begin{array}{c}m g / 100 \\
m l\end{array}$ & $\begin{array}{c}\text { mg/24 } \\
\text { hours }\end{array}$ & $\begin{array}{c}\text { ml/ } \\
\text { min }\end{array}$ \\
& & 3.3 & 733 & 15.6 \\
SD & Pulmonary abscess & 4.3 & 1,330 & 21.5 \\
OII & Lobar pneumonia & 4.5 & 1,280 & 19.8 \\
MS & Bronchiectasis & 3.8 & 1,164 & 21.3 \\
OF & Septic arthritis & 2.2 & 918 & 29.0 \\
JP & Rheumatoid arthritis & 4.7 & 1,296 & 19.1 \\
CK & Rheumatoid arthritis & 4.2 & 1,035 & 17.1 \\
JI & Rheumatic fever & 4.2 & &
\end{tabular}

* Renal clearance of uric acid. 
Certain observations, reported both here and previously, favor increased production of uric acid as the mechanism for the increased excretion. The leukocytosis observed during the symptomatic state (Table I) indicates increased nucleic acid production and, after degeneration of the leukocytes in the inflammatory area, increased uric acid production. A previously reported observation on the ability of iv administered desoxyribonuclease to increase uric acid excretion in symptomatic gouty subjects tends to confirm this concept (1). This enzyme, a DNA depolymerase, is capable of diffusing into inflammatory areas and depolymerizing DNA derived from susceptible leukocytes (11-13).

The failure to demonstrate an increase in serum uric acid levels argues against the concept of increased production. Recent studies have shown that increased uric acid load, in addition to producing increased renal clearance of uric acid, also increases serum levels (14-16). The observation, however, of normal serum uric acid levels in nongouty subjects with increased uric acid production secondary to suppurative and inflammatory diseases (Table IV) suggests that inflammation may modify the host response to an increased uric acid load. The increased urinary excretion of 17-hydroxycorticosteroids during the symptomatic state by five of the gouty subjects (Table I) implies an increased secretion of adrenal steroids during the pain and stress of the arthritis that would produce renal uricosuria (17) and possibly decrease serum levels despite an increased load.

The second question, whether the increased excretion of uric acid is a cause or effect of the arthritis, must also be answered speculatively. The increased uric acid excretion by two subjects before development of clinical arthritis (Table III) indicates the increase may be causally related. The classical observations that leukocytosis-stimulating episodes such as infection, surgery, or trauma are precipitating causes of arthritis (1820) support this possibility. The arthritis itself, however, will stimulate further leukocytic response, and further nucleic acid and uric acid production, and, as Seegmiller, Laster, and Howell postulate, the inflammatory reaction becomes selfsustaining and self-enhancing (21).

\section{SUM MARY}

Data demonstrate that gouty subjects have a greater excretion and clearance of uric acid while they are symptomatic, but that their serum levels do not change predictably with the symptoms. The cause of these changes is unknown, but the leukocytosis and increased 17-hydroxycorticosteroid excretion observed during the arthritic state suggest the combined involvement of increased production of uric acid and steroid-induced renal uricosuria.

\section{ACKNOWLEDGMENT}

We are indebted for the excellent technical assistance of Miss Giannina Zatti and for the co-operation of $\mathrm{Mr}$. Milton Weissman with the 17-hydroxycorticosteroid analyses.

\section{REFERENCES}

1. Ayvazian, J. H., and L. F. Ayvazian. Effect of intravenous administration of crystalline pancreatic desoxyribonuclease in patients with gout. New Engl. J. Med. 1960, 263, 999.

2. Brøchner-Mortensen, $K$. The uric acid content in blood and urine in health and disease. Medicine 1940, 19, 161.

3. Ludwig, A. O., G. A. Bennett, and W. Bauer. A rare manifestation of gout: widespread ankylosis simulating rheumatoid arthritis. Ann. inter. Med. 1938, 11, 1248.

4. Talbott, J. H., B. M. Jacobson, and S. A. Oberg. The electrolyte balance in acute gout. J. clin. Invest. 1935, 14, 411.

5. Stetten, D., Jr. Gout. Perspect. Biol. Med. 1959, 2, 185.

6. Ayvazian, J. H., and L. F. Ayvazian. A study of the hyperuricemia induced by hydrochlorothiazide and acetazolamide separately and in combination. J. clin. Invest. 1961, 40, 1961.

7. Prætorius, E., and H. Poulsen. Enzymatic determination of uric acid with detailed directions. Scand. J. clin. Lab. Invest. 1953, 5, 273.

8. Fister, H. J. Manual of Standardized Procedures for Spectrophotometric Chemistry. New York, Standard Scientific Supply Corp., 1950, p. 728.

9. Silber, R. H., and C. C. Porter. The determination of 17,21-dihydroxy-20-ketosteroids in urine and plasma. J. biol. Chem. 1954, 210, 923.

10. Wilcoxan, F. Some Rapid Approximate Statistical Procedures. New York, American Cyanamid Co., 1949.

11. Johnson, A. J., P. R. Goger, and W. S. Tillett. The intravenous injection of bovine crystalline pancreatic desoxyribonuclease into patients. J. clin. Invest. 1954, 33, 1670. 
12. Ayvazian, J. H., A. J. Johnson, and W. S. Tillett. The use of parenterally administered pancreatic desoxyribonuclease as an adjunct in the treatment of pulmonary abscesses. Amer. Rev. Tuberc. 1957, $76,1$.

13. Johnson, A. J., J. H. Ayvazian, and W. S. Tillett. Crystalline pancreatic desoxyribonuclease as an adjunct to the treatment of pneumococcal meningitis. New Engl. J. Med. 1959, 260, 893.

14. Nugent, C. A., and F. H. Tyler. The renal excretion of uric acid in patients with gout and in nongouty subjects. J. clin. Invest. 1959, 38, 1890.

15. Lathem, W., and G. P. Rodnan. Impairment of uric acid excretion in gout. J. clin. Invest. 1962, 41, 1955.

16. Yü, T. F., L. Berger, and A. B. Gutman. Renal function in gout. II. Effect of uric acid loading on renal excretion of uric acid. Amer. J. Med. 1962, 33, 829 .

17. Ingbar, S. H., E. H. Kass, C. H. Burnett, A. S. Relman, B. A. Burrows, and J. H. Sisson. The effects of ACTH and cortisone on the renal tubular transport of uric acid, phosphorus, and electrolytes in patients with normal renal and adrenal function. J. Lab. clin. Med. 1951, 38, 533.

18. Talbott, J. H. Gouty arthritis. Current concepts in treatment and control. Minn. Med. 1959, 42, 1044.

19. Hoffman, W. S. Some unsolved problems of gout. Med. Clin. N. Amer. 1959, 43, 595.

20. Bartels, E. C. Gout. Postgrad. Med. 1954, 15, 255.

21. Seegmiller, J. E., L. Laster, and R. R. Howell. Biochemistry of uric acid and its relation to gout. New Engl. J. Med. 1963, 268, 821. 